\title{
Effects of Graded Crude Protein Diet on Haematological Indices and Body Weight of African Giant Rat (Cricetomys gambianus)
}

\author{
${ }^{1,2}$ Olawuwo, O. S., ${ }^{3,4 *}$ Olaogun, S. C., ${ }^{1}$ Azeez, O. I. and ${ }^{1}$ Oyewale, J.O.
}

\begin{abstract}
${ }^{1}$ Department of Veterinary Physiology and Biochemistry, Faculty of Veterinary Medicine, University of Ibadan, Nigeria.
${ }^{2}$ Paraclinical Science Department, Faculty of Veterinary Science, University of Pretoria, Onderstepoort 0110, Pretoria, South Africa.

${ }^{3}$ Department of Veterinary Medicine, Faculty of Veterinary Medicine, University of Ibadan, Nigeria.

${ }^{4}$ Department of Production Animal Studies, Faculty of Veterinary Science, University of Pretoria, Onderstepoort 0110, Pretoria, South Africa.
\end{abstract}

*Author for Correspondence: charle.sunday@yahoo.com

\begin{abstract}
The domestication of the African giant rat (AGRs) (Cricetomys gambianus) to compliment the inadequate animal protein supplies in Nigeria and its potential to serve as a model for biomedical research is yet to be fully exploited. This study determines the effects of varied crude protein (CP) diet on haematological indices and body weight of AGRs. Blood samples were obtained from the orbital sinus of 30 apparently healthy adult male and female AGRs. The AGR's were kept in captivity and divided into 6 rats per group (A, B, C, D and E). Group A served as control group. The groups were fed with graded levels of crude protein (CP) of (E) $9.83 \%$, (D) $14.79 \%$, (A) $21.21 \%$, (C) $23.93 \%$ and (B) $27.84 \%$. Each chloroform pre-anaesthetized AGRs were weighed at days 0 and 14, 28, 42 and 56, while blood samples were collected at days 28 and 56 . The samples were each analyzed for erythrocyte and leucocyte parameters and platelet counts by standard methods. All data collected were subjected to analysis of variance and student t-test. At 28 days post-feeding, AGRs fed with $27.84 \%$ CP showed no significant elevations in erythrocyte and leucocyte values compared with control values $(21.21 \% \mathrm{CP})$. However, at 56 days post-feeding, $\mathrm{RBC}, \mathrm{Hb}, \mathrm{PCV}$, total WBC, eosinophil, lymphocyte and monocyte counts were significantly lowered in the group fed with $27.84 \%$ CP. No significant differences in body weights were observed in rats that were fed $27.84 \%, 21.21 \%, 14.8 \%$ and $9.8 \%$ crude protein diets for 28 and 56 days. This study shows improved body weight with $27.84 \%$ CP compared with other crude protein percentage used while $14.79 \% \mathrm{CP}$ had the best haematological parameters when compared with other crude protein groups.
\end{abstract}

Keywords: African giant rats; Crude protein; Haematology; Weight

\section{INTRODUCTION}

The African giant rat (AGR) (Cricetomys gambianus, Waterhouse) is a large wild rodent with adult mean body weight ranging from 0.86-1.13 kg (Oyewaleet al., 1998). Also known as the Gambian pouched rat, it is native to Africa, belonging to the class Rodentia, and is a representative of the Muridae family (Cooper, 2008). In local Nigerian parlance, they are called Ewi in Igbo language, Burugu in Hausa and Okete in Yoruba. The African giant rat is widely distributed in Nigeria, but more abundant in the savannah regions of the country (Ajayi and Tewe, 1983). The rat is believed to be a highly intelligent mammal with the ability to use varieties of materials like soil, stones, soiled bedding as a plug to the main entrance of its hole during the day to protect itself from intruders and predators (Ajayi, 1974). Phenotypically, the African giant rat is distinguished from other giant rats by its very long tail with a distinguishing white tip. Also, it gets its distinctive name from its elastic bag-like mouth cavity that can only be compared to a marsupial pouch (Ajayi et al., 1978). African giant rat can be domesticated and be raised or reared as a potential source of income and also to provide an important means of animal protein for both rural and urban dwellers. Much information about this animal such as feeding, watering, reproductive characteristic and behaviour needs to be unveiled. Basically, in the wild, reports have it that this animal fed on forages including Pennisetum purpureum (elephant grass), Panicum maximum (guinea grass), Saccharum spp (sugar cane); herbaceous legumes like Stylosanthes spp (stylo) and Pueraria phaseoloides (tropical kudzu) (Marani,2018). Ajayi and Tewe, (1980) reported that elephant grass was the most consumed grass by cane rats in their study. However, some of these gramineous species especially the Pennisetum purpureum (elephant grass) and Panicum maximum (guinea grass) are found to have low protein and vitamin levels and usually result to high wastage of the feed, which makes feed supplementation a necessity in captivity (NtiamoahBaidu,1998; Scharage and Yewadan, 1999). 
Several feed rations attempts have been made to determine the most optimum feed for the AGRs in captivity. For instance, Ajayi and Tewe (1983) reported that feeding of the African giant rats with commercial pig ration improves the growth performance when the protein level was raised from 10 to $13 \%$. Cooper (2008) also reported that African giant rat requires more protein than the other laboratory rats.

The blood has been described as the most important and reliable medium for assessing the health status of animals (Oduye, 1976; Anosa, 1983). Haematological indices reflect the physiological responsiveness of the animal to its internal and external environment, which includes quality and quantity of feed, feeding regime and other management practices (Esonu et al., 2001). Animal nutritionists agree that feed ingredients, including unconventional feedstuffs, affect nimal physiology (Emenalom and Udedibie, 1998). $\mathrm{H}$ aematological parameters are also valuable in monitoring toxicity especially with feed constituents that affect the process of erythropoiesis (Oyawoye and Ogunkunle, 1998). Addass et al. (2012) Addass et al., (2012) reported on influence of dietary component on haematological parameters as well as (Aya et al., 2013) who reported on effects of consumption of processed feeds on the haematological values of animals. Specifically, dietary content affects the blood profile of healthy animals (Odunsi et al., 1999; Yeong, 1999; Iheukwumere and Herbert, 2002; Kurtoglu et al., 2005). Correlation between diet, feed intake and final weight gain has also been previously described in broiler chicken to be one of the determinants of the final weight gain (Adegbenjo et al., 2015)

Domestication of this animal species will require appropriate formulation of a nutritional diet which, will supports optimum growth and reproductive capacity of the animal. For successful domestication of African giant rat, there is a need for proper feeding, together with adequate provision of health and management measures. Haematologi cal indices and weight changes will be good indicators for the assessment of the suitability and correspondent benefit of an experimental diet on a wild species of animal such as African giant rat. The baseline or reference data provided by this study will be an invaluable guide in the management and treatment of African giant rat both in the wild, and in captivity.

\section{MATERIALS AND METHODS}

\section{Experimental Site}

The study was carried out at the African giant rats Research Unit in the Department of Veterinary Physiology and Biochemistry, University of Ibadan, Nigeria. (Latitude $7^{\circ}$ $23^{\prime}$ 8.19"N and Longitude $3^{\circ} 54^{\prime}$ 59.99"E). Average temperature of $26.5^{\circ} \mathrm{C}$ and mean annual rainfall of $1311 \mathrm{~mm}$ existed during the experimental period (Google Earth, 2012).

\section{Ethical Statement}

The protocol was approved by the Animal Care and research Ethics Committee (ACUREC) of the University of Ibadan, Ibadan, Nigeria with approval reference number UIACUREC/App/12/2016/04.

\section{Experimental Animal and Management}

Thirty apparently healthy adult wild African giant rats (Cricetomys gambianus, Waterhouse) of both sexes were purchased from a local market in Ibadan, Nigeria. They were each housed in a separate cage in the animal house of the Department of Veterinary Physiology and Biochemistry, University of Ibadan, Nigeria. The rats were fed on a commercially available diet of pelletized grower feed $(15 \%$ crude protein; $7 \%$ fat; $10 \%$ crude fibre; $1.0 \%$ calcium; $0.35 \%$ phosphorus; $2,550 \mathrm{kcal} / \mathrm{kg}$ metabolizable energy, Vital Feeds Limited, Jos, Nigeria). The feeds and water were provided ad libitum. Feeding was also supplemented with palm kernel fruits and yam peelings. The rats were placed on Neomycin-Oxytetracycline $\mathrm{HCL}^{\circledR}$ (Neimeth Inter.Pharm Plc, Lagos) and dewormed with piperazine hydrochloride (Wormazine ${ }^{\circledR}$ ) (Alfasan International BV344AB Woerden, Holland) at $1 \mathrm{~g} / 1$ of water 2 weeks before the commencement of the study.

\section{Experimental Design}

\section{Effects of Graded Crude Protein in Diets}

Five semi - purified diets were formulated with graded protein levels of group A $(21.21 \%, \mathrm{n}=6$; control), group B $(27.84 \%, \mathrm{n}=6)$ and group $\mathrm{C}(23.93 \%, \mathrm{n}=6)$, group $\mathrm{D}$ $(14.79 \%, n=6)$ and group $E(9.83 \%, n=6)$ according to Cooper (2008). Each diet was fed to the different rat groups for 56 days. Each rat was weighed before the commencement of the study and fed at $5 \mathrm{gm} / 100 \mathrm{gm}$ body weight. Again, the rats were sampled and weighed after acclimatization at day 0 and 14, 28, 42 and 56 days postfeeding. Blood samples were collected from the retro-orbital venous plexus of each rat after chloroform anaesthesia, into bottles containing ethylene diamine tetra acetic acid (EDTA) (2 $\mathrm{mg} / \mathrm{ml}$ of blood) for haematological analysis. Some of the AGRs died during the course of the experiment.

\section{Proximate Analysis}

Dry matter (DM) was determined by drying at $80^{\circ} \mathrm{C}$ for 48 $\mathrm{h}$; ash was measured in a muffle furnace at $510^{\circ} \mathrm{C}$ for $18 \mathrm{~h}$. Crude protein of samples was determined by the Kjeldahl method and the ether extract by a Soxhlet apparatus. Other analysis was carried out according to the methods outlined by the Association of Official Analytical Chemists (DeVries, 2004). We took group A with crude protein of $21.21 \%$ as our standard (control) based on the recommendation by Cooper (2008) who recommended 20\% crude protein as minimum requirement for African giant rats.

\section{Haematological Analysis}

The whole blood samples (from EDTA bottles) were used to determine haematological measurements. Packed cell volume (PCV), Haemoglobin (HB), and Red blood cell (RBC) were determined using Wintrobes microhaematocrit, colorimetry- cyanomethaemoglobin method and improved Neubauer haemocytometer respectively. WBC was determined with a Wintrobes haematocrit tube according to the method of Schalm et al. (1975). The WBC differentials counts were carried out on blood smears stained with May- 
Grunwald-Giemsa stain. Mean corpuscular haemoglobin concentration (MCHC) and mean corpuscular haemoglobin (MCH) were computed according to Jain (1986).

\section{Determination of Body Weight}

Body weights of African giant rats were taken at the beginning of the experiment and at every two weeks until day 56 of the study. Body weight gain/loss was recorded as the difference between the initial day 0 and final body weight day 56 for each group of the crude protein diet (AE). Mathematically body weight gain was calculated as: Body weight gain $(\mathrm{g})$ = final weight-initial weight . Percentage weight gain was calculated as: weight gain/loss (g) $\div$ initial weight $\times 100$.

\section{Statistical Analysis}

The data were expressed as mean \pm SEM. One- way ANOVA was used for the test of significance between groups that were more than two, and Tukey's post-hoc test was used to compare means of all samples using Graphpad Prism, version 4.00, April, 2003 Statistical Software Chicago, IL, USA. Student's t test was also used to compare two sample means where applicable. $p<0.05$ was considered significant. (www.graphpad.com).

\section{RESULTS}

Table 1 shows gross composition (\%) of varied crude protein experimental diets (A-E) for the African giant rats. The feed ingredients used were maize, soya meal, palm kernel cake, wheat offal, fish meal (72\%) and Daram Vitamix ${ }^{\circledR}$ premix (at $2.5 \mathrm{~kg} /$ ton of feed).

Table 2 shows proximate analysis of chemical composition $(\%)$ of the graded experimental diets (A-E) for the giant rats. The feed compositions based on proximate analysis are crude protein, dry matter, ash, crude fiber, crude fat, moisture content and carbohydrate. Group B feed had the highest crude protein $(27.84 \%)$ while group $\mathrm{E}$ had the least crude protein $(9.83 \%)$.

The Erythrocyte parameters of the remaining 27AGRs after losing 3 out of 30 AGRs 28 days post - feeding with graded crude protein diets are shown in Table 3. No significant differences in the values of $\mathrm{PCV}, \mathrm{RBC}, \mathrm{Hb}, \mathrm{MCV}, \mathrm{MCH}$ and $\mathrm{MCHC}$ were apparent 28 days post - feeding between the rat groups that received $21.21 \%, 27.84 \%, 23.93 \%$, $14.79 \%$ and $9.83 \%$ crude protein diets.

Table 4 shows the leucocytes parameters of the AGRs after 28 days feeding trial. Like the erythrocyte parameters, no significant differences in the values of the total and differential WBC and platelet counts were seen with the rat groups fed with $21.21 \%, 27.84 \%, 23.93 \%, 14.79 \%$ and $9.83 \%$ crude protein diets.

The erythrocytic indices values of 22 remaining AGRs after losing 8AGRs at 56 days after consuming the graded crude protein diet are shown in Table 5. The result showed that the $\mathrm{PCV}, \mathrm{RBC}$ and $\mathrm{Hb}$ values in the rats fed $27.84 \%$ crude protein were each significantly lower $(p<0.05)$ compared to the corresponding values in the control rats. The levels of $\mathrm{PCV}, \mathrm{RBC}$ and $\mathrm{Hb}$ in the rats fed $23.93 \%, 14.79 \%$ or $9.83 \%$ crude protein however did not differ significantly $(p>0.05)$ from the values in the control rats (fed $21.21 \%$ crude protein) while there was no significant difference $(\mathrm{p}>0.05)$ from the control value (fed $21.21 \%$ crude protein) and between treatment groups in the $\mathrm{MCV}, \mathrm{MCH}$ and $\mathrm{MCHC}$ in rats fed $27.84 \%, 23.93 \%, 14.79 \%$ or $9.83 \%$ crude protein diets.

Table 6 shows the leucocyte parameters at 56 days post feeding. The total WBC and lymphocyte count in rats fed $27.84 \%$ and $23.93 \%$ crude protein for 56 days were each significantly lower $(\mathrm{p}<0.05)$ than the value in the control rats which received $21.21 \%$ crude protein for the same duration. Similarly, the eosinophil count in rats fed $27.84 \%$ was significantly lower $(\mathrm{p}<0.05)$ than the corresponding value in the control rats. The monocyte count in rats fed $27.84 \%, 23.93 \%, 14.79 \%$ and $9.83 \%$ were each significantly lower $(\mathrm{p}<0.05)$ than the corresponding value in the control rats while there were no significant difference $(p>0.05)$ from the control value (fed $21.21 \%$ crude protein) and between other treatment groups in the neutrophil, basophil and platelet counts in rats fed $27.84 \%, 23.93 \%, 14.79 \%$ or $9.83 \%$ crude protein diets after 56 days.

Table 7 shows the body weights of giant rats fed graded crude protein diets for $0,14,28,42$ and 56 days. There were no statistically significant differences in body weights in rats that received $21.21 \%, 27.84 \%, 23.93 \%, 14.79 \%$ and $9.83 \%$ crude protein diets for the entire period of the study.

Marginal weight gain or loss during the 8 weeks study period was also calculated as shown in Table 8. Comparison between day 0 and day 56 average body weight of the African giant rats showed marginal weight gain in group B$\mathrm{E}$, the marginal weight loss $(-4.57 \%)$ was seen in group $\mathrm{A}$ $(21.21 \%)$ crude protein diet. Highest percentage weight gain $(31.87 \%)$ was recorded in group C $(23.93 \%)$ crude protein diet.

\section{DISCUSSION}

In the effort of various researchers to unravel the feeding requirements of the AGR towards their domestication, there has been conflicting reports on the crude protein requirement in African giant rats. Ajayi and Tewe (1978) showed that there was an improvement in the growth performance of giant rats with increase in dietary protein level from $10 \%$ to $13 \%$ while Cooper (2008) recommended $20 \%$ crude protein as minimum requirement for African giant rats. Findings from this present study revealed two out of the five feed groups analyzed (groups D\&E) agreed with (Ajayi and Tewe, 1978) and other three groups of feed agreed with Cooper (2008) recommendation of $20 \%$ crude protein as the three groups have more than $20 \%$ crude protein. This implies that $9-14 \%$ crude protein in the diet is adequate for improved weight gain in the AGR, although, high protein diet of about $23.93 \%$ CP showed the highest weight gain. Therefore, other factors may be responsible for this weight gain.

Hematological parameters are important indicators of the physiological and pathological status for both humans and animals (Adeneye et al., 2006). 
Table 1: Gross Composition (\%) of Experimental Diets for African Giant Rats

\begin{tabular}{llllll}
\hline Ingredients & A (Control) & B & C & D & E \\
\hline Maize & 62 & 50 & 43 & 76 & 81 \\
Soya Meal & 22 & 33 & 38 & 9 & 1 \\
Palm Kernel Cake & 5 & 8 & 3 & 3 & 3 \\
Wheat Offal & 5 & 4 & 3 & 9 & 14 \\
Fish Meal (72\%) & 5 & 8 & 12 & 4 & - \\
Grower Premix & 1 & 1 & 1 & 1 & 1 \\
\hline Total & 100 & 100 & 100 & 100 & 100 \\
\hline
\end{tabular}

Daram Vitamix ${ }^{\mathrm{R}}$ ( Daram Nig.Ltd) was added in a proportion of $2.5 \mathrm{~kg} / \mathrm{ton}$ of feed. This provides additional vitamins and minerals.

Table 2: Chemical Composition (\%) of Experimental Diets for African Giant Rats

\begin{tabular}{lccccc}
\hline Composition (\%) & $\begin{array}{c}\text { A } \\
\text { (Control) }\end{array}$ & B & C & D & E \\
\hline Crude Protein & 21.21 & 27.84 & 23.93 & 14.79 & 9.83 \\
Dry Matter & 90.82 & 91.38 & 91.59 & 90.96 & 90.87 \\
Ash & 6.41 & 6.56 & 6.49 & 6.33 & 6.28 \\
Crude Fibre & 4.13 & 3.97 & 4.35 & 4.46 & 4.54 \\
Crude Fat & 3.62 & 8.19 & 3.65 & 3.72 & 3.68 \\
Moisture Content & 9.98 & 8.19 & 8.63 & 9.05 & 9.13 \\
Carbohydrate & 55.45 & 49.70 & 52.95 & 61.67 & 66.55 \\
\hline
\end{tabular}

Table 3: Erythrocyte Values of Adult African Giant Rats (Cricetomys gambianus) 28 days Post Feeding with Graded Crude Protein Diets

\begin{tabular}{llllllll}
\hline $\begin{array}{l}\text { Crude Protein } \\
\text { (CP) Diet }\end{array}$ & (n) & $\begin{array}{l}\text { PCV } \\
(\%)\end{array}$ & $\begin{array}{l}\text { RBC } \\
(\mathbf{1 0} / \boldsymbol{\mu L})\end{array}$ & $\begin{array}{l}\text { Hb } \\
\text { (g/dL) }\end{array}$ & $\begin{array}{l}\text { MCV } \\
\text { (fL) }\end{array}$ & $\begin{array}{l}\text { MCH } \\
\text { (pg) }\end{array}$ & $\begin{array}{l}\text { MCHC } \\
\text { (g/dL) }\end{array}$ \\
\hline (A) Control (21.21 \% CP) & 6 & $47.83 \pm 1.28$ & $9.24 \pm 0.60$ & $16.17 \pm 0.40$ & $54.10 \pm 2.12$ & $17.76 \pm 2.13$ & $33.82 \pm 0.45$ \\
(B) 27.84\% CP & 5 & $44.60 \pm 1.38$ & $8.22 \pm 0.30$ & $14.60 \pm 0.54$ & $54.36 \pm 0.98$ & $17.39 \pm 0.67$ & $32.72 \pm 0.54$ \\
(C) $23.93 \%$ CP & 4 & $46.50 \pm 1.73$ & $9.07 \pm 0.92$ & $15.50 \pm 0.57$ & $52.37 \pm 3.01$ & $17.46 \pm 1.03$ & $33.34 \pm 0.65$ \\
(D) 14.79\% CP & 6 & $46.83 \pm 1.25$ & $8.40 \pm 0.44$ & $16.17 \pm 0.71$ & $56.11 \pm 1.43$ & $19.32 \pm 0.57$ & $34.45 \pm 0.78$ \\
(E) $9.83 \%$ CP & 6 & $46.33 \pm 1.95$ & $8.94 \pm 0.65$ & $15.50 \pm 0.89$ & $52.41 \pm 1.64$ & $17.45 \pm 0.47$ & $32.61 \pm 0.95$ \\
\hline
\end{tabular}

$\mathrm{p}<0.05$ was considered significant.

It can also be used to establish the extent of negative effect of foreign compounds, including grains and food products, on the blood of the albino rats as described by (Odeyemi et al., 2009). In this study, varied crude protein diets did not have a significant influence on erythrocyte values and indices such as $\mathrm{PCV}, \mathrm{Hb}$ concentration, $\mathrm{RBC}$ count, $\mathrm{MCV}, \mathrm{MCHC}$ and $\mathrm{MCH} 28$ days post-feeding while significant difference was observed 56 days post-feeding in $\mathrm{PCV}, \mathrm{Hb}$ concentration and RBC count. However, high crude protein diet of up to $27.84 \%$ is not useful in terms of improvement in haematological parameters. These improved values of PCV, RBC and $\mathrm{Hb}$ indicate a haematinic and blood enhancer potential of the graded crude protein pelleted feed. This increase in PCV, Hb and RBC may possibly be as a result of the level of the ash content of the feed samples. The minerals contain in the ash including iron $(\mathrm{Fe})$ and Copper $(\mathrm{Cu})$ plays important roles in haemoglobin synthesis. The higher values of RBC and associated parameters are suggestive of polycythemia (American Diabetes Association,
2000). This is similar to the report of Aderemi (2004) that haematological traits, especially, $\mathrm{PCV}$ and $\mathrm{Hb}$ were correlated with the nutritional status of the animal. Also, Afolabi et al. (2010) observed that nutrition had significant effect on haematological values like PCV, $\mathrm{Hb}$ and RBC. Togun et al. (2007) reported that increase in PCV coupled with the marginal increase in $\mathrm{RBC}$ is indicative of more efficient erythropoiesis in experimental rabbits. Ahmed et al. (1994) observed that MCHC values decrease with increase in the level of protein, which is contrary to our findings in which no significant difference was observed 28 and 56 days post-feeding.

This may be due to differences in crude protein composition in the two studies. In a manner that is similar to that of the erythrocyte indices 28 days postfeeding, varied crude protein diets did not have a significant influence on leucocytes values and platelet count until 56 days post-feeding in which total WBC, eosinophils, lymphocyte and monocytes values displayed significant difference across the treatment groups 
Sahel J. Vet. Sci. Vol. 17, No. 4, Pp. 8-15

Table 4: Leucocyte Values of Adult African Giant Rats (Cricetomys gambianus) 28 days Post Feeding with Graded Crude Protein Diets. Crude protein (CP) diet

\begin{tabular}{ll} 
(n) & $\begin{array}{l}\text { Total WBC } \\
(\mathbf{x 1 0} / \boldsymbol{\mu L})\end{array}$ \\
6 & $8.81 \pm 0.39$ \\
5 & $7.94 \pm 0.23$ \\
4 & $7.90 \pm 0.34$ \\
6 & $8.88 \pm 0.72$ \\
6 & $9.78 \pm 0.99$ \\
\hline
\end{tabular}

$\begin{aligned} & \text { Neutrophils } \\ & (\mathbf{x 1 0} / \boldsymbol{\mu} \mathbf{L})\end{aligned}$
$5.68 \pm 0.19$
$4.95 \pm 0.38$
$4.92 \pm 0.26$
$6.31 \pm 0.90$
$6.63 \pm 0.76$

$\begin{aligned} & \text { Basophils } \\ & \left(\mathbf{x} 10^{3} / \boldsymbol{\mu L}\right)\end{aligned}$
$0.00 \pm 0.00$ Eosinophils

$(\mathbf{x 1 0} / \boldsymbol{\mu L})$

Lymphocytes

Monocytes $\left(\mathbf{x 1 0 ^ { 3 } / \mu \mathrm { L } )}\right.$

Platelets

(A) $21.21 \% \mathrm{CP}$

(C) $23.93 \% \mathrm{CP}$

$0.00 \pm 0.00$

$2.83 \pm 0.27$

$0.14 \pm 0.03$

(D) $14.79 \% \mathrm{CP}$

$9.78 \pm 0.99$

$0.00 \pm 0.00$

$0.00 \pm 0.00$

$3.08 \pm 0.46$

$0.12 \pm 0.03$

$692.00 \pm 44.64$

(E) $9.83 \% \mathrm{CP}$

$6.63 \pm 0.76$

$0.00 \pm 0.00$

$0.12 \pm 0.02 \quad 2.66 \pm 0.21$

$0.10 \pm 0.02$

$0.14+0.03$

$667.80 \pm 56.03$

Values are means \pm SEM; $n=$ Number of animals. $p<0.05$ was considered significant $0.14 \pm 0.06$

$2.66 \pm 0.21$
$2.85 \pm 0.19$

$0.13 \pm 0.04$

$700.67 \pm 34.59$

$687.33 \pm 69.20$

Table 5: Variations in Erythrocyte Values of Adult African Giant Rats (Cricetomys gambianus) 56 days Post Feeding with Graded Crude Protein Diets.

\begin{tabular}{|c|c|c|c|c|c|c|c|}
\hline Crude protein (CP) diet & (n) & PCV (\%) & $\operatorname{RBC}\left(10^{6} / \mu \mathrm{L}\right)$ & $\mathrm{Hb}(\mathrm{g} / \mathrm{dL})$ & MCV (fL) & MCH (pg) & MCHC (g/dL) \\
\hline (A) $(21.21 \% \mathrm{CP}$ & 4 & $50.50 \pm 0.46^{\mathrm{a}}$ & $9.86 \pm 0.12^{\mathrm{a}}$ & $17.25 \pm 0.34^{\mathrm{a}}$ & $51.32 \pm 0.93$ & $17.51 \pm 0.37$ & $34.15 \pm 0.52$ \\
\hline (B) $27.84 \% \mathrm{CP}$ & 5 & $44.80 \pm 1.34^{\mathrm{b}}$ & $8.03 \pm 0.16^{\mathrm{b}}$ & $15.20 \pm 0.52^{b}$ & 1.77 & $18.92 \pm 0.56$ & 0.45 \\
\hline (C) $23.93 \% \mathrm{CP}$ & 4 & $48.50 \pm 1.06^{\mathrm{a}}$ & $10.30 \pm 0.85^{\mathrm{a}}$ & $16.50 \pm 0.35^{\mathrm{a}}$ & $47.56 \pm 2.90$ & $16.18 \pm 0.99$ & $34.00 \pm 0.00$ \\
\hline (D) $14.79 \% \mathrm{CP}$ & 4 & $49.25 \pm 0.74^{\mathrm{a}}$ & $9.30 \pm 0.73^{\mathrm{a}}$ & $17.00 \pm 0.35^{\mathrm{a}}$ & $58.80 \pm 5.81$ & $18.90 \pm 2.00$ & $34.53 \pm 0.78$ \\
\hline (E) $9.83 \% \mathrm{CP}$ & 5 & $48.00 \pm 1.24^{\mathrm{a}}$ & $9.23 \pm 0.36^{\mathrm{a}}$ & $16.60 \pm 0.42^{\mathrm{a}}$ & $52.32 \pm 1.19$ & $18.10 \pm 0.46$ & $34.59 \pm 0.21$ \\
\hline
\end{tabular}

$16.60 \pm 0.42^{\mathrm{a}}$

$52.32 \pm 1.19$

$18.90 \pm 2.00$

$34.53 \pm 0.78$

Mean values with different superscript letters in the same column are significantly different $(\mathrm{p}<0.05)$

Table 6: Leucocyte Values of Adult African Giant Rats (Cricetomys gambianus) 56 days Post Feeding with Graded Crude Protein Diets.

\begin{tabular}{|c|c|c|c|c|c|c|c|c|}
\hline Crude protein (CP) diet & (n) & $\begin{array}{l}\text { Total WBC } \\
\left(x^{3} 0^{3} / \mu \mathrm{L}\right)\end{array}$ & $\begin{array}{l}\text { Neutrophils } \\
\left(x^{3} 0^{3} / \mu \mathrm{L}\right)\end{array}$ & $\begin{array}{l}\text { Basophils } \\
\left(\times 10^{3} / \mu \mathrm{L}\right)\end{array}$ & $\begin{array}{l}\text { Eosinophils } \\
\left(x^{3} 0^{3} / \mu \mathrm{L}\right)\end{array}$ & $\begin{array}{l}\text { Lymphocyte } \\
\left(\times 10^{3} / \mu \mathrm{L}\right)\end{array}$ & $\begin{array}{l}\text { Monocytes } \\
\left(x_{10}^{3} / \mu \mathrm{L}\right)\end{array}$ & $\begin{array}{l}\text { Platelets } \\
\left(\times 10^{3} / \mu \mathrm{L}\right)\end{array}$ \\
\hline (A) $21.21 \% \mathrm{CP}$ & 4 & $9.07 \pm 0.18^{\mathrm{a}}$ & $5.78 \pm 0.28$ & $0.09 \pm 0.02$ & $0.09 \pm 0.05^{\mathrm{a}}$ & $3.21 \pm 0.17^{\mathrm{a}}$ & $0.18 \pm 0.09^{\mathrm{a}}$ & $619.50 \pm 25.50$ \\
\hline (B) $27.84 \% \mathrm{CP}$ & 5 & $7.78 \pm 0.23^{\mathrm{b}}$ & $5.54 \pm 0.18$ & $0.00 \pm 0.00$ & $0.07 \pm 0.03^{b}$ & $2.22 \pm 0.13^{\mathrm{b}}$ & $0.08 \pm 0.04^{\mathrm{b}}$ & $699.00 \pm 46.74$ \\
\hline (C) $23.93 \% \mathrm{CP}$ & 4 & $7.78 \pm 0.08^{\mathrm{b}}$ & $5.53 \pm 0.28$ & $0.00 \pm 0.00$ & $0.00 \pm 0.00$ & $2.14 \pm 0.27^{b}$ & $0.16 \pm 0.01^{\mathrm{c}}$ & $627.50 \pm 18.79$ \\
\hline (D) $14.79 \% \mathrm{CP}$ & 4 & $8.67 \pm 0.59^{\mathrm{a}}$ & $5.43 \pm 0.25$ & $0.00 \pm 0.00$ & $0.11 \pm 0.05^{\mathrm{c}}$ & $3.16 \pm 0.34$ & $0.14 \pm 0.03^{\mathrm{d}}$ & $690.00 \pm 33.58$ \\
\hline (E) $9.83 \% \mathrm{CP}$ & 5 & $9.25 \pm 0.63^{\mathrm{a}}$ & $5.75 \pm 0.42$ & $0.07 \pm 0.02$ & $0.11 \pm 0.05^{\mathrm{c}}$ & $3.42 \pm 0.26^{\mathrm{a}}$ & $0.16 \pm 0.01^{\mathrm{e}}$ & $753.80 \pm 58.94$ \\
\hline
\end{tabular}

Values are means \pm SEM; $\mathrm{n}=$ Number of animals; Percentage leucocyte values in parentheses. Mean values with different superscript letters in the same column are

significantly different $(\mathrm{p}<0.05)$. 
Sahel J. Vet. Sci. Vol. 17, No. 4, Pp. 8-15

Table 7: Body Weights (g) of Wild Adult African Giant Rats Fed on Graded Crude Proteins (g)

Crude protein (CP) diet

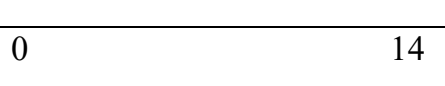

14

\begin{tabular}{lcccc}
\hline (A) $21.21 \% \mathrm{CP}$ & $860.67 \pm 68.26$ & $877.67 \pm 51.25$ & $835.00 \pm 33.86$ & $800.00 \pm 50.78$ \\
(B) $27.84 \% \mathrm{CP}$ & $826.67 \pm 120.65$ & $933.33 \pm 123.84$ & $906.80 \pm 124.73$ & $888.60 \pm 121.00$ \\
(C) $23.93 \% \mathrm{CP}$ & $617.50 \pm 90.78$ & $673.20 \pm 76.20$ & $788.00 \pm 89.64$ & $837.33 \pm 90.58$ \\
(D) $14.79 \% \mathrm{CP}$ & $846.67 \pm 62.56$ & $850.00 \pm 62.58$ & $893.33 \pm 60.25$ & $88.33 \pm 83.77$ \\
(E) $9.83 \% \mathrm{CP}$ & $723.33 \pm 84.29$ & $746.67 \pm 67.72$ & $793.50 \pm 83.80$ & $814.33 \pm 123.98$ \\
\hline \multicolumn{4}{l}{ Values are means \pm SEM; Feeding $=5 \mathrm{~g}$ of feed per 100g body weight of African giant rat. $\mathrm{p}<0.05$ was considered significant }
\end{tabular}

\section{Days Post-Feeding} 28

\begin{tabular}{lcccc}
\hline (A) $21.21 \% \mathrm{CP}$ & $860.67 \pm 68.26$ & $877.67 \pm 51.25$ & $835.00 \pm 33.86$ & $800.00 \pm 50.78$ \\
(B) $27.84 \% \mathrm{CP}$ & $826.67 \pm 120.65$ & $933.33 \pm 123.84$ & $906.80 \pm 124.73$ & $888.60 \pm 121.00$ \\
(C) $23.93 \% \mathrm{CP}$ & $617.50 \pm 90.78$ & $673.20 \pm 76.20$ & $788.00 \pm 89.64$ & $837.33 \pm 90.58$ \\
(D) $14.79 \% \mathrm{CP}$ & $846.67 \pm 62.56$ & $850.00 \pm 62.58$ & $893.33 \pm 60.25$ & $88.33 \pm 83.77$ \\
(E) $9.83 \% \mathrm{CP}$ & $723.33 \pm 84.29$ & $746.67 \pm 67.72$ & $793.50 \pm 83.80$ & $814.33 \pm 123.98$ \\
\hline \multicolumn{4}{l}{ Values are means \pm SEM; Feeding $=5 \mathrm{~g}$ of feed per 100g body weight of African giant rat. $\mathrm{p}<0.05$ was considered significant }
\end{tabular}

42

\begin{tabular}{lcccc}
\hline (A) $21.21 \%$ CP & $860.67 \pm 68.26$ & $877.67 \pm 51.25$ & $835.00 \pm 33.86$ & $800.00 \pm 50.78$ \\
(B) $27.84 \%$ CP & $826.67 \pm 120.65$ & $933.33 \pm 123.84$ & $906.80 \pm 124.73$ & $888.60 \pm 121.00$ \\
(C) $23.93 \%$ CP & $617.50 \pm 90.78$ & $673.20 \pm 76.20$ & $788.00 \pm 89.64$ & $837.33 \pm 90.58$ \\
(D) $14.79 \%$ CP & $846.67 \pm 62.56$ & $850.00 \pm 62.58$ & $893.33 \pm 60.25$ & $810.20 \pm 111.16$ \\
(E) $9.83 \%$ CP & $723.33 \pm 84.29$ & $746.67 \pm 67.72$ & $793.50 \pm 83.80$ & $889.60 \pm 64.12$ \\
\hline \multicolumn{2}{l}{ Values are means \pm SEM; Feeding $=5$ g of feed per 100g body weight of African giant rat. $p<0.05$ was considered significant }
\end{tabular}

Values are means \pm SEM; Feeding $=5 \mathrm{~g}$ of feed per $100 \mathrm{~g}$ body weight of African giant rat. $\mathrm{p}<0.05$ was considered significant

Table 8: Average Body Weight gain/loss in (g) of Per African Giant Rat Fed on Graded Crude Proteins (g) Group A-E.

\begin{tabular}{llcc}
\hline $\begin{array}{l}\text { Graded Crude Protein } \\
\text { (CP) Diet }\end{array}$ & Weight (g) Day 0 & Weight (g) Day 56 & Weight gain/loss (g) \\
\hline (A) $21.21 \%$ CP & $860.67 \pm 68.26$ & $821.33 \pm 83.77$ & -39.34 \\
(B) $27.84 \%$ CP & $826.67 \pm 120.65$ & $840.20 \pm 111.16$ & 13.53 \\
(C) $23.93 \%$ CP & $617.50 \pm 90.78$ & $814.33 \pm 123.98$ & 196.83 \\
(D) $14.79 \%$ CP & $846.67 \pm 62.56$ & $957.50 \pm 47.84$ & 1.64 \\
(E) $9.83 \%$ CP & $723.33 \pm 84.29$ & $862.60 \pm 69.66$ & 110.83 \\
\hline Values are means + SEM; Feeding $=5 \mathrm{~g}$ of feed per 100g body weight of African giant rat. $p<0.05$ was considered significant & 13.09 \\
\hline
\end{tabular}

(E) $9.83 \% \mathrm{CP}$

$862.60 \pm 69.66$

139.27

Values are means \pm SEM; Feeding $=5 \mathrm{~g}$ of feed per $100 \mathrm{~g}$ body weight of African giant rat. $\mathrm{p}<0.05$ was considered significant

In a manner that is similar to that of the erythrocyte indices 28 days post-feeding, varied crude protein diets did not have a significant influence on leucocytes values and platelet count until 56 days post-feeding in which total WBC, eosinophils, lymphocyte and monocytes values displayed significant difference across the treatment groups. Olafedehan et al. (2010) in their study on the effect of residual cyanide in processed cassava peel meal on haematological indices of growing rabbits observed that with the exception of neutrophil and eosinophil, other haematological parameters were significantly affected by the dietary treatments and this is similar to our findings. White blood cells (WBC) are important in defending the body against infection (Aboderin and Oyetayo, 2006). The white blood cell count however cannot give a definite or specific information but the result of a differential white blood cell count (Neutrophils, Eosinophils, Monocyte, Lymphocytes and Basophils) narrows down to give specific information about infections, toxicity allergy and immuno-suppression and poisoning (Aboderin and Oyetayo, 2006)

The significant difference in values of white blood cells observed in this study agrees with the findings of Lawrence-Azua et al. (2013) on the haematological indices of growing rabbits fed enzyme supplemented cocoa bean shell. After feeding four dietary treatments formulated to contain $0 \%, 10 \%, 20 \%$ and $30 \%$ of cocoa bean shell as a replacement for maize.

Summarily, this study showed that most of the haematological parameters of African giant rats (AGRs) are altered by dietary protein levels. This might be a factor to consider in management decisions and health status assessment. In addition, the variation in the hematological parameters of giant rats as a result of varied crude protein diets in this study can be effectively utilized as indices in the evaluation of protein requirement of the captive African giant rats, which can lead to commercial production of cheaper feeds for its domestication 
The performance of African giant rats fed on graded crude protein shows improved weight gain in the entire groups from the beginning to the end of the study. Though, weight loss was observed in the control group (A) which may be due to some other factors. Combined observations from this study indicate that the giant rat can be raised on the locally available commercial rations. Reduction in the weight of some rats at the early stage or even during the period of the study may be due to different feed intake by the rats which may be associated with variation in crude protein level in all diet groups. Though, there was no significant difference $(p>0.05)$ in the daily weight gain in all the groups, but all groups apart from the control group recorded higher numerical values. This may be related to acclimatization to captivity environment that the rats were not previously used to. The result of weight gain as recorded in this study agrees with the reports of Ademola et al. (2004) who reported no significant difference $(p>0.05)$ in average live weight, feed intake and feed conversion ratio of broiler chickens fed herbal supplements

\section{Conclusion}

The findings of this study showed that African giant rats can survive on pelleted feed with improved weight gain, haematological indices and liveability. Further studies should be carried out on alternative domestication methods such as semi-intensive and combined feeds.

\section{Acknowledgements}

The inputs of Kola Alatise and Johnson Agbokhaode who helped to provide nursing care during the experimental phase are gratefully acknowledged. We also acknowledged the technical staff of the department of Veterinary Physiology, Biochemistry and Pharmacology laboratory, University of Ibadan, Nigeria.

\section{Conflict of interest:}

The authors declare that they do not have any conflict of interest.

\section{Grants}

No research grant was obtained from this study.

\section{Authors' contributions}

OSO and OIA performed the experiment, JOO supervised the project, SCO wrote the manuscript draft.

\section{REFERENCES}

Aboderin, F.I. and Oyetayo, V.O. (2006). Haematological Studies of rats fed different doses of probiotic, Lactobacillus Plantarum, Isolated from fermenting Corn Slurry. Pak J. Nut., 5(2): 102-105.

Addass, P. A., David, D. I., Edward, A., Zira, K. E. and Midau, A. (2012). Effect of age, sex and management system on some haematological parameters of intensively and semi-intensively kept chicken in Mubi, Adamawa State, Nigeria. Iran J. Appl Anim. Sci.,2(3):277-282.

Adegbenjo, A. A., Oluwatosin, O. O., Jegede, A. V., Oso, A. O., Fafiolu, A. O. and Ogunbanke, E. A. (2015). Performance and haematological indices of broiler chickens fed diets containing supplements of three phytogenic plants. Bull Anim. Health Prod. Afri., 63(3): 335-347.

Adeneye, A.A., Ajagbonna, O.P. and Bello, S.O. (2006). Preliminary toxicity and Phytochemical studies of the stem bark aqueous extract of Musanga cecropioides in rats. $J$ Ethnopharmacol., 105(3): 373-379

Aderemi, F. A. (2004). Effects of replacement of wheat bran with cassava root sieviate supplemented or unsupplemented with enzyme on the haematology and serum biochemistry of pullet chicks. Trop. J. Anim. Sci., 7:147-153.

Afolabi, K. D., Akinsoyinii, A. O., Olajide, R. and Akinleye, S. B. (2010). Haematological parameters of the Nigerian local grower chickens fed varying dietary levels of palm kernel cake. Proceeding of the 35th Annual Conference of the Nigeria Society for Animal Production. Pp:247.

Ahmed, M. K., Bargue, A. R., Nawaz, H. and Siddiqui, R. H. (1994). Effect of varying energy and protein levels of the haematology of Japanese quail. Pak. Vet J., 14(4): 200-202.

Ajayi S. S, Tewe O. O. and Faturoti E. O. (1978). Behavioural changes in the African giant rat (Cricetomys gambianus Waterhouse) under domestication. E. Afr. Wildl. J . , 16,137-143.

Ajayi, S.S. and Tewe, O.O. (1983). Quantitative assessment of wildlife and their nutritive value as a source of food in Nigeria. Nutrition and food policy in Nigeria/edited by Tola Atinmo, Laolu Akinyele. Pp 138-146

Ajayi, S.S. and Tewe, O.O. (1980). Food preference and carcass composition of the grass cutter (Thryonomyss winderianus) in captivity. African J. Ecology, 18(2-3), pp.133-140.

Ajayi, S. S. (1977). Live and carcass weights of giant rat Cricetomys gambianus Waterhouse and domestic rabbit Oryctolagus cuniculus L. Afri J. Ecol., 15(3) , 223-227.

Ajayi,S.S (1974). Giant rats for meat and some taboos. Oryx $12,379-80$

American Diabetes Association, (2000). Nutrition Recommendation and Principles for Diabetes mellitus, Clinical Practice recommendations. Diabetes Care 23: 543-546.

Anosa, V.O. (1983): Mammalian blood cells in health and trypanosomiasis. Trop. Vet., 1:177-199.

Aya, V. E., Ayanwale, B. A., Ijaiya, A. T. and Aremu, A. (2013). Haematological and serum biochemistry indices of broiler chickens fed rumen filtrate fermented palm kernel meal based diet. Proceedings of the $18^{\text {th }}$ Annual Conference of Animal Science Association of Nigeria. Pp:329.

Babatunde, G.M and Olusanya, O.A. (1992): Rubber seed oil versus palm oil in broiler chickens diet. Effect on performance, nutrient digestibility, haematology and carcass characteristics. Anim. Feed. Sci. Tech., 35: 133-146. 
Coles, E.H. (1986). Determination of packed cell volume.In: Coles, E.H. (Ed). Veterinary Clinical Pathology, pp. 17-19.

Cooper, R.G. (2008). Care, husbandry and diseases of the African Giant rat (Cricetomys gambianus). J. South Afri. Vet. Assoc., 79:62-66.

DeVries, J. W. (2004). Dietary fiber: the influence of definition on analysis and regulation. J. $A O A C$ Inter., 87(3): 682-706.

Emenalom, O.O. and A.B.I. Udedibie, (1998). Effect of dietary raw, cooked, toasted Mucunapruriens seed (velvet bean) on the performance of finisher broilers. Nigeria. J. Anim Prod., 25: 115-119.

Esonu B. O., Iheukwemere, F.C.,Emenalom, O. O.,Udebibie ,A.B., Herbert, U.,Ekpor, C.F. and Okolie,I.C. (200 1). Performance and blood chemistry of weaner pig fed Mucunapruriens (velvet bean) meal. Trop. Anim. Prod. Inv., 4:49-54.

Google Earth (2012). Google earth http//www.google.earth. January -June, 2015.

Iheukwumere, F. C. and Herbert, U. (2002). Physiological responses of broiler chickens to quantitative water restrictions: haematology and serum biochemistry. J. Poult. Sci., 2:117-119.

Jain N.C. (1986). Schalm's Veterinary Haematology. $4^{\text {th }}$ ed. Lea and Febiger, Philadelphia, U.S.A., pp. 1221.

Kurtoglu, F., Kurtoglu, V., Celik, I., Kececi, I. and Nizamlioglu, M. (2005). Effect of dietary boron supplementation on some biochemical parameters, peripheral blood lymphocytes, splenic plasma cells and bone characteristics of broiler chicks given diets with adequate or inadequate cholecalciferol (Vitamin D) content. British. Poult. Sci., 46:87-96.

Lawrence-Azua, O. O., Odetola, O. M., Awe, A. O. and Yahaya, M. O (2013). Performance and haematological indices of growing rabbits fed enzyme supplemented cocoa bean shell. Proceedings of the 18th Annual Conference of Animal Science Association of Nigeria. Pp:169.

Marani, S. A. M. (2018). Effects of pelleted feed on the performance of the grasscutter (Thryonomyss winderianus). J. Agric. Sci. Food Res, 9, 218.

Ntiamoah-Baidu Y (1998) Sustainable Use of Bushmeat. A Wildlife Development Plan (1998-2003), Wild Life Development Accra 6: 78.

Odeyemi, O.O., Yakubu, M.T., Masika, P.J. and Afolayan, A.J. (2009). Toxicological evaluation of the essential oil from Mentha Longifolia L Suosp. Capensis Leaves in rats. J. Med. Food.,12(3): 669674.

Odunsi, A. A., Ojifade, A. A. and Babatunde, G. M. (1999). Response of broiler chicks to virginmycin and dietary protein concentration in the humid tropics. Archivfür Zoologie und Zootomie.48(183):317-325.
Oduye, O. O. (1976). Haematological values of Nigerian goats and sheep. Trop. J. Anim. Hlth .Prod., 8, 131136.

Olabanji, R.O., Ojebiyi, O.O., Tona, G.O. and Ologun, O. (2009). Haematological and serum biochemical response of growing rabbits fed diets containing processed mango (Mangiferaindica). in: J.A. Akinlade., T.B. Olayeni., T.A Rafiu., A.O Akinwunmi., O.A Aderinola., O.O Ojebiyi and Odunsi, A.A (eds.) Global Economic Recession and the Challenges to Livestock Production in Nigeria. Proceedings of the 14th annual conference of Animal Science Association of Nigeria held at Ladoke Akintola University of Technology, Ogbomoso, Oyo State, Nigeria.pp: 170-173.

Olafedehan, C. O., Obun, A. M., Yusuf, M. K., Adewumi, O. O., Olafedehan, A. O., Awofolaji, A. O. and Adeniji, A. A. (2010). Effects of residual cyanide in processed cassava peel meals on haematological and biochemical indices of growing rabbits. Proceedings of the 35th Annual Conference of the Nigerian Society for Animal Production. Pp:212.

Oyawoye EO, Ogunkunle M. (1998): Physiological and biochemical effects of raw jack beans on broilers. Proceedings of annual Conference of Nigerian Society of Animal production. 23: 141-142.

Oyewale, J.O; Oke, O.A, Olayemi, F.O. and Ogunsanmi, A.O. (1998).Electrolyte enzyme, protein and metabolite Levels in the blood plasma of the wild adult African giant rat (Cricetomys gambianus, water house).Veterinarski. Arhiv., 68:127 133.

Prescott, J.F. and Baggot, J.D(1993). Antimicrobial Therapy in Veterinary Medicine, $2^{\text {nd }} e d n$. IOWA State University Press, Pp: 564-565.

Schalm, O. W., Jain, N. C and Carroll, E. J. (1975). Veterinary hematology (No. 3rd edition). Lea \& Febiger.

Scharage, R. and Yewadan LT (1999) Feeds and Feeding. Raising Grasscutters, GTZ (Germany), pp: 1-90.

Theml, H., Diem, H. and Haferlach, T. (2004). Color Atlas of Haematology: Practical Microscopic and Clinical Diagnosis. Thieme Stuttgart and New York.

Togun, V. A., Oseni, B. S. A., Ogundipe, J. A., Arewa, T. R., Hammed, A.A., Ajonijebu, D. C., Oyeniran, A., Nwosisi, I. and Mustapha, F. (2007). Effects of chronic lead administration on the haematological parameters of rabbit - a preliminary study. Proceedings of the 41st Conference of the Agricultural Society of Nigeria. Pp: 341.

Yeong, S. W. (1999). Effect of dietary protein on growth performance of village chicken. Proceedings of National IRPA Seminar Agric Sector. Pp: 25192520 . 